\title{
The abilities of managers in UK pension funds. Are socially responsible managers superior?
}

Mercedes Alda ${ }^{1}$

Universidad de Zaragoza (España)

Recibido el 23 de noviembre de 2015, aceptado el 20 de marzo de 2017

$\mathrm{N}^{\circ}$ de clasificación JEL: G12, G23

DOI: $10.5295 / \mathrm{cdg} .150597 \mathrm{ma}$

\begin{abstract}
:
The abilities of managers in pension funds and, especially, in Socially Responsible (SR) pension funds have only rarely been investigated. Both standard pension funds and specialized SR funds are concerned with social welfare, but SR pension funds present a special interest of study. Various works show that SR managers usually underperform conventional funds because they focus on social aspects, although other studies find that SR funds overperform. In this work, the stock-picking and style timing abilities of UK conventional and SR equity pension fund managers are studied, examining whether SR pension funds implement different strategies and contribute to developing more socially responsible outcomes. Additionally, the influence of SR as a risk factor is introduced. As far as is known, style timing and the introduction of the SR risk factor have not been previously studied in the context of SR pension funds. The results indicate that both kinds of pension fund develop similar investment strategies, investing in small cap and growth values. Moreover, both funds present negative performance, poor/ negative stock-picking abilities, and perverse market timing abilities. SR managers exhibit superior style timing skills and are able to correctly time size and book-to-market strategies. The SR risk factor shows that SR pension funds have significantly positive loadings of this factor, which erodes their performance. Overall, none of the funds analyzed develop proper management, and the optimization of the risk-return binomial in SR funds may be constrained by SRI requirements.
\end{abstract}

Keywords:

Pension fund, selectivity, skill, timing, United Kingdom.

Resumen:

Las habilidades de los gestores de fondos de pensiones, especialmente de fondos socialmente responsables (SR), apenas han sido analizadas. Los fondos de pensiones y los fondos SR se preocupan por el bienestar social, por lo que el estudio de los fondos de pensiones SR presenta un interés especial. Diversos trabajos muestran que los gestores SR generalmente presentan una performance inferior a la de los fondos convencionales, ya que se centran en aspectos sociales; sin embargo, otros estudios muestran que estos presentan mejor performance.

1 Facultad de Economía y Empresa, C/Gran Vía, 2, C.P.50005, Zaragoza (España).malda@unizar.es 
The abilities of managers in UK pension funds. Are socially responsible managers superior?

En este trabajo se estudian las habilidades de selección de valores y sincronización de estilos de los gestores de fondos de pensiones de renta variable de Reino Unido, examinando si los fondos de pensiones SR implementan estrategias diferentes y contribuyen a formar pensiones socialmente responsables. Además, se introduce la responsabilidad social como factor de riesgo. Dado lo que me es conocido, la sincronización de estilos y el factor SR no han sido analizados previamente en fondos de pensiones SR. Los resultados indican que ambos fondos desarrollan estrategias similares, invirtiendo en empresas de pequeña capitalización y en crecimiento. Además, presentan una performance negativa, una habilidad de selección de valores pobre o negativa, y una habilidad de sincronización con el mercado negativa. Los gestores SR muestran mejor habilidad de sincronización en estilos, sincronizando correctamente estrategias tamaño y book-to-market. Los fondos de pensiones SR tienen un peso significativamente positivo en el factor $S R$, lo que erosiona su performance. En general, ninguno de los fondos analizados desarrolla una gestión adecuada, y la optimización del binomio riesgo-rentabilidad en fondos SR puede estar restringida por las exigencias de la inversión SR.

\section{Palabras clave:}

Fondo de pensiones, selección, habilidad, sincronización, Reino Unido. 


\section{INTRODUCTION}

Globally, Socially Responsible Investment (SRI) has grown significantly over the past two decades. Although SRI can be defined in a variety of ways, the Social Investment Forum (SIF) (2001) specifies that SRI is "an investment process that considers the social and environmental consequences of investments, both positive and negative, within the context of rigorous financial analysis (Social Investment Forum 2001)”. Eurosif (2011) indicates that SRI is a concept that continues to evolve as both established and newer financial services players develop new methods and approaches to the valuation and incorporation of environmental, social, and governance (ESG) issues in fund management.

This investment is based on the fact that consumers pay a premium for products and companies that are consistent with their personal values: environmental protection, human rights, labor relations...; these companies assume a responsibility towards society, the environment, and stakeholders in general. Investors avoid companies that may cause health hazards (alcohol, tobacco, gambling...) or exploit employees. This contrasts with the traditional view of maximizing value for the shareholders by considering purely financial aspects. Nonetheless, the SRI idea is based on both social welfare and value maximization.

Many studies have examined the performance of SR financial products, specifically SR mutual funds, but the empirical evidence of these analyses is mixed. Some authors state that there is no conflict between the two goals (financial and non-financial). The majority of SR mutual fund studies attain similar performance results to conventional fund studies (Camino and López 1995; Becchetti and Fucito 2000), and some works find superior results (Read 1999). However, other authors (Munnell 1983; Lamb 1991; Luther et al. 1992) posit that SRI involves a financial sacrifice, while still others, such as Domini et al. (1992), Waddock and Graves (1997) and Davis (1999), argue that ethical investment implies a premium.

Despite this, SRI has grown considerably in the last two decades, although its development varies considerably from one country to another. European SRI reached $€ 22.89$ billion Euros in 2015, according to Eurosif (2016), and the United Kingdom ( $€ 4.5$ billion), France ( $€ 3.7$ billion) and the Netherlands ( $€ 3$ billion) are the top three European countries in terms of SRI (Eurosif 2016). Furthermore, the UK fund management in SRI has experienced a remarkable growth in recent years, distinguishing their commitment to SRI in pension funds (Eurosif 2016). Specifically, in 2016, the UK Pensions Regulator included in its defined-contribution pension scheme practice code that trustees may also consider non-financial factors in which pension participants share their concern.

This growth may be partly attributed to regulatory changes in relation to the disclosure of social, environmental, and ethical (SEE) information, and/or ethical, social, and corporate governance (ESG) information by pension funds and listed companies. For example, the United Kingdom was the first country to regulate the disclosure of the SEE investment policies of pension funds and charities, contributing considerably to the growth of the industry, especially occupational plans, as Clark and Hebb (2005) indicate.

However, SR practices are still developing in pension funds, and there is a progressive awareness of their importance. Pension funds are integrating extra-financial analysis into the decision-making process, with SR pension fund net assets representing $0.89 \%$ of the overall pension fund net assets at the end of 2009. 
The data shows that $65.3 \%$ of European SR assets are held by pension funds. However, $98.1 \%$ ( $€ 3,161$ billion) of these assets are held by public pension funds and $1.9 \%$ ( $€ 61$ billion) by occupational pension plans (Hertrich 2011). Some evidence shows that corporate pension funds intend to expand their SR allocation; for example, in Spain, SRI has grown recently in the institutional market; , although it is only important in occupational pension funds, as Albareda and Balaguer (2009) explain.

Given these circumstances, few studies have examined SR pension funds and there are conflicting views on SRI. Supporters argue that the practice has advantages for pension funds and the economy, because the wellbeing of many citizens depends on pension fund performance. Specifically, the concept is that pension funds are powerful institutional investors that may ensure economic stability and stable environmental, social and corporate governance conditions in the global economies. As a consequence, as Clark and Hebb (2005), Sethi (2005), and Hawley and Williams (2007) indicate, this stability leads to more prosperous economies and healthier financial returns for pension funds.

On the other hand, critics claim that non-financial criteria influence pension fund decision making and increase exposure to financial risks; that is, it is in conflict with fiduciary duty. Hoepner et al. (2011) conclude that pension fund fiduciary duties should not forbid ESG criteria in the investment process. Indeed, Eurosif (2011) explains that ESG criteria should be a part of fiduciary duty.

In this study, a sample of UK domestic equity pension funds is analyzed, dividing the sample into conventional and socially responsible pension funds. Specifically, their performance and managerial skills (stock picking, market timing, and style timing) are compared (aspects rarely analyzed previously in SR pension funds). Indeed, as far as is known, this study presents the first comparative analysis of style timing abilities. Additionally, the influence of SR as a risk factor is introduced.

The organization of the paper is as follows: Section 2 presents a literature review, Section 3 describes the methodology, Section 4 explains the data and results, and Section 5 concludes.

\section{LITERATURE REVIEW}

Initially, the use of non-financial investment criteria was mainly based on religious beliefs, although it was marginal (Sparkes and Cowton 2004; Bengtsson 2008a, 2008b; Richardson and Cragg 2010). Today, many institutions (mutual funds, pension funds, governmental and non-governmental organizations) integrate SR in their investment strategies (Emel 2002; Gifford 2010; Derwall et al. 2011).

The majority of SR studies analyze SR mutual funds and most of them focus on the UK or the US. Luther et al. (1992), Mallin et al. (1995) and Gregory and Whittaker (2007) are based on the UK market. Goldreyer and Diltz (1999), Statman (2000) and Geczy et al. (2006) analyze the US market. Other works analyze other markets: Bauer et al. (2005), Kreandert et al. (2005) and Bauer et al. (2006) study the Australian case; Bauer et al. (2007) examine the Canadian market, and Renneboog et al. (2008) evaluate several other countries. 
However, SR pension fund studies are less common. This may be due to the debate on the appropriateness of including SR criteria in pension fund investment strategy.

Proponents of SR pension funds cite a range of reasons. First, SR represents an investment strategy that delivers attractive risk-adjusted returns (Clark and Hebb 2005; Sethi 2005; Kiernan 2007). Second, pension funds and other institutional investors own the majority of global financial assets and performance depends on financial markets. Hence, these institutions have an incentive to integrate any SR criteria that affect the world economy in their investment process (Hawley and Williams 2000, 2007; Amalric 2006; Thamotheram and Wildsmith 2007; Mattison et al. 2011). Third, pension funds should be responsible for societal well-being, as well as the natural environment, including them in their investment (Lydenberg 2007; Richardson 2008; Solomon 2009; Berry 2011).

Although the criticisms are minor, they point to several motives. First, SRI interferes in pension fund strategies and is financially risky (Entine 2005; Munnel and Sundén 2005; Rounds 2005). In this sense, pension funds should only work for diversification and high-risk-adjusted return by investing according to the risk parameters of the investment policies (UNEP Finance Initiative 2005; Richardson 2007; Berry 2011). Despite this, as Solomon (2009) indicates, pension funds and other investment institutions need to appreciate the value of engaging in an SRI strategy.

In this regard, Eurosif (2011) develops one of the first complete European studies on pension funds and responsible investment, explaining that SRI affects long-term performance, and many pension funds feel that SRI policies are part of their fiduciary duty. This implies that some pension funds are lacking in their fiduciary duty by not having a SRI policy.

SR mutual fund studies usually focus on comparing performance with their counterparts, although the analysis of managers' performance and skills is rare in SR pension funds. Only Ferruz et al. (2010) evaluate UK global equity pension funds (SR and conventional), finding a slight stock picking ability of SR pension fund managers, and negative market timing ability of both SR and conventional managers. These authors also observe that, while conventional pension fund managers make certain use of superior information to follow stock-picking strategies, SR pension fund managers use superior information to follow market timing strategies.

Given this limited evidence, this study evaluates whether the SR managers of UK domestic equity pension funds develop better performance and managerial skills than their counterparts. Additionally, the first comparative analysis of style timing abilities and the inclusion of SR style in pension funds are presented.

\section{METHODOLOGY}

\subsection{Performance measure}

To analyze the financial performance of SR and conventional pension funds, the CAPM model is applied:

$$
r_{i t}=\alpha_{0}+\beta_{1} r_{\text {set }}+\varepsilon_{i t}
$$


Where: $\mathrm{r}_{\mathrm{it}}=\mathrm{R}_{\mathrm{it}}-\mathrm{R}_{\mathrm{ft}}$ is the excess return of fund $i$ at time $t$ over the risk-free asset; $\mathrm{r}_{\mathrm{mt}}=$ $\mathrm{R}_{\mathrm{mt}}-\mathrm{R}_{\mathrm{ft}}$ is the excess benchmark return over the risk-free asset; $\beta$ is the beta of the fund with the market, which represents the systematic risk; $\alpha_{0}$ is the CAPM-adjusted return of SR/ conventional pension fund portfolios; and $\varepsilon_{i t}$ is the error term.

In the second stage, the 4-factor Carhart model (Carhart 1997) is applied. Some of the most recent papers about financial performance of SR mutual funds have implemented this methodology (Bauer et al. 2005; Bauer et al. 2006; Bauer et al. 2007; Kempf and Osthoff 2007; Climent and Soriano 2011; Ferruz et al. 2012):

$$
r_{i f}=\alpha_{0}+\beta_{1} r_{m t}+\beta_{2} S M B_{i}+\beta_{3} H M L_{i}+\beta_{4} P R 1 Y R_{t}+\varepsilon_{i t}
$$

Where: $\mathrm{r}_{\mathrm{it}}$ is the excess return of fund $i$ in period $t$ over the risk-free asset; $r_{m t}$ is the excess return of a representative market index over the risk-free asset in period $t$; SMB is the size factor; HML is the book-to-market factor ${ }^{2}$; and PR1YR represents the momentum factor. The European factors (SMB, HML, PR1 YR) used are those developed by Fama and French $^{3}$.

\subsection{Traditional market timing models}

Various models have been used in the financial literature to identify stock-picking and market timing abilities. Two of the most used are Treynor and Mazuy (TM) (1966) and Merton and Henriksson (MH) (1981) models.

The Treynor and Mazuy (1966) model is expressed as follows:

$$
\mathrm{r}_{\mathrm{it}}=\alpha_{0}+\beta_{1} \mathrm{r}_{\mathrm{mt}}+\gamma_{1} \mathrm{r}_{\mathrm{mt}}^{2}+\varepsilon_{i t}
$$

where: $\mathrm{r}_{\mathrm{it}}=\mathrm{R}_{\mathrm{it}}-\mathrm{R}_{\mathrm{ft}}$, and $\mathrm{r}_{\mathrm{mt}}=\mathrm{R}_{\mathrm{mt}}-\mathrm{R}_{\mathrm{ft}}$ are the excess return of fund $i$ and the excess market return over the risk-free asset $f$ during the period $t$, respectively; $\alpha_{0}$ represents the stock-picking ability of the manager, that is, the ability to select securities that provide higher returns than others with the same level of non-diversifiable risk. A positive and significant alpha indicates correct stock-picking, and $\gamma_{1}$ determines the market timing skill. If the gamma coefficient $\left(\gamma_{1}\right)$ is positive and significant, the manager has market timing ability; if $\gamma_{1}$ is negative and significant, the timing ability is perverse. Finally, $\varepsilon_{i t}$ is the term of the error and its expected value is zero.

The Merton and Henriksson (1981) model has the following expression:

$$
\mathrm{I}_{\mathrm{if}}=\alpha_{0}+\beta_{1} r_{\mathrm{set}}+\gamma_{1}\left[r_{\mathrm{mit}}\right]^{+}+\varepsilon_{\text {if }}
$$

Where: $\mathrm{r}_{\mathrm{it}}=\mathrm{R}_{\mathrm{it}}-\mathrm{R}_{\mathrm{ft}}$, and $\mathrm{r}_{\mathrm{mt}}=\mathrm{R}_{\mathrm{mt}}-\mathrm{R}_{\mathrm{ft}}$ are the excess return of fund $i$ and the market return over the risk-free asset $f$ during the period $t$, respectively; $\alpha_{0}$ represents the stock-picking ability; $\gamma_{1}$ measures the market timing ability; $\left[r_{\mathrm{set}}\right]^{-}=\operatorname{Max}\left[0, r_{\mathrm{m} \text { e }}\right]$ is the

2 A more detailed description can be found in Fama and French (1993).

3 Data available on the website of Fama and French: http://mba.tuck.dartmouth.edu/pages/faculty/ken.french/ data_library.html\#Developed 
payment of an option over the market portfolio with a strike price equal to the risk-free asset; and $\varepsilon_{i t}$ is the error term.

\subsection{Conditional market timing models}

The two traditional timing models previously explained are unconditional models, in that they do not distinguish between the use of public information and superior information, which means that any information correlated with future market returns is interpreted as privileged information. Additionally, these models assume that the alpha, beta, and gamma coefficients do not vary over time.

To overcome these assumptions, Ferson and Schadt (1966) and Ferson and Quian (2004) develop some conditional versions, distinguishing market timing based on public information from that based on superior information.

The new version of the Treynor and Mazuy model (1966) includes certain lagged information variables to control whether the manager has superior information:

$$
\mathrm{r}_{\mathrm{it}}=\alpha_{0}+\beta_{1} \mathrm{r}_{\mathrm{m}}+\beta_{2}\left(\mathrm{z}_{\mathrm{t}-1} \mathrm{r}_{\mathrm{mt}}\right)+\gamma_{1} \mathrm{r}_{\mathrm{mt}}^{2}+\gamma_{2}\left(\mathrm{z}_{\mathrm{i}-1} \mathrm{r}_{\mathrm{mt}}^{2}\right)+\varepsilon_{i t}
$$

where $\mathrm{z}_{\mathrm{t}-1}$ is a vector of public economic cycle information variables and can predict the market risk premium; $\beta_{2}\left(z_{t-1} r_{m t}\right)$ controls the common time variation in the risk premium and the portfolio beta due to public information.

Similarly, Ferson and Schadt (1996) and Ferson and Quian (2004) propose the conditional version of the MH model:

$$
\mathrm{r}_{\mathrm{it}}=\alpha_{0}+\beta_{1} r_{\mathrm{ret}}+\beta_{2}\left[z_{t-1} r_{\mathrm{str}}\right]+\gamma_{1}\left[r_{\mathrm{sr}}\right]^{+}+\gamma_{2}\left[z_{t-1} r_{\mathrm{ret}}\right]^{+}+\varepsilon_{i t}
$$

where $\gamma_{2}\left[z_{t-1} r_{\text {st }}\right]^{*}$ captures the variability of the manager's timing ability over the economic cycle due to the use of public information.

In conditional models (5) and (6), the three information variables that represent the economic cycle are those used by Ferson and Schadt (1996), Christopherson et al. (1998), Cortez and Silva (2002) and Roy and Deb (2004), since these authors have proven their relevance in explaining returns on securities and bonds. Specifically:

- Return per dividend: calculated as the quotient between the dividends paid by MSCI-UK over the previous 12 months and the current index price.

- Time spread: calculated as the difference between the annualised return on the UK bond at 10 years and the Libor rate at 3 months.

- Short-term interest rate: represented by the Libor rate at 1 month.

\subsection{Style timing models: multifactorial timing versions}

In this section, the timing abilities with regard to market and specific factors/styles are analyzed. If a manager develops these skills, the manager would increase the importance of those styles, enhancing the performance of the portfolio.

For this purpose, Bollen and Busse (2001) take the multifactorial performance models of Fama and French (1993) and Carhart (1997) and propose an extension of the TM model (1966), considering the factors of those models. The extension is carried out in Bollen and Busse (2001), as in the following formula: 


$$
r_{i t}=\alpha_{0}+\sum_{j=1}^{4} \beta_{j} r_{j}+\gamma r_{* t}^{2}+\varepsilon_{i}
$$

where the sum of $j$ factors refers to the four factors of the Carhart (1997) model. Then, Lu (2005) incorporates the Carhart factors in the TM (1966) model:

$$
\begin{aligned}
& r_{i r}=\alpha_{0}+\beta_{1} r_{m r}+\beta_{2} S M B_{r}+\beta_{3} H M L_{t}+\beta_{4} P R 1 Y R_{r}+ \\
& \gamma_{1} r_{m t}^{2}+\gamma_{2} S M B_{t}^{2}+\gamma_{3} H M L_{i}^{2}+\gamma_{4} P R 1 Y R_{t}^{2}+\varepsilon_{i t}
\end{aligned}
$$

This model assesses whether a pension fund manager increases (decreases) his/her risk exposure to a specific factor prior to the factor index increase (decrease). The fund return will be a convex function of the factor index return. A positive gamma coefficient indicates style timing ability with regard to this management style.

The Merton and Henriksson (1981) model is also extended by Lu (2005) to measure style timing:

$$
\begin{aligned}
& r_{i r}=\alpha_{0}+\beta_{1} r_{m r}+\beta_{2} S M B_{r}+\beta_{3} H M L_{t}+\beta_{4} P R 1 Y R_{r}+ \\
& \gamma_{1} r_{m t}^{*}+\gamma_{2} S M B_{t}^{*}+\gamma_{3} H M L_{2}^{*}+\gamma_{4} P R 1 Y R_{t}^{*}+\varepsilon_{i t}
\end{aligned}
$$

where: $\operatorname{Max}\left[0, r_{m t}\right], S M B_{t}^{*}=\operatorname{Max}[0, S M B], H M L_{t}^{*}=\operatorname{Max}[0, H M L], P R 1 Y R_{t}^{*}=\operatorname{Max}[0, P R 1 Y R]$

\subsection{The SR risk factor}

Renneboog et al. (2008) indicate that the underperformance found by some SR mutual fund studies is due to two factors. First, models do not incorporate an SRI/ethical risk factor, so this factor may not be fully captured by the benchmarks (CAPM or Fama-French-Carhart factors). As a consequence, adding this factor to the four-factor model could improve the alphas of ethical/SR funds.

Second, these authors argue that companies with high ethical standards may be overpriced as a result of an 'aversion to unethical/asocial corporate behavior'. This can lead to a situation in which SR investors claim to invest in SR firms, although they obtain lower returns. Rising demand may cause these firms to be priced above their fundamental value as ethical funds underperform the market.

To control for the potential style differences between SR and conventional pension funds, this factor is added to the four-factor model:

$$
r_{i t}=\alpha_{0}+\beta_{1} r_{m t}+\beta_{2} S M B_{t}+\beta_{3} H M L_{t}+\beta_{4} P R 1 Y R_{t}+\beta_{s} r_{t}^{s R}+\varepsilon_{u t}
$$

Where: $\alpha$ is the five-factor alpha of pension funds; $r_{t}^{s r}$ captures the excess return of the SR index, $\beta_{5}$ is the loading on the SR risk factor, and $\varepsilon_{\mathrm{it}}$ stands for the idiosyncratic return. $r_{t}^{s r}$ can also be interpreted as a zero-investment spread that has a long position in SR pension funds and a short position in a risk-free deposit. The SR factor returns, following Renneboog et al. (2008), are measured by an SR equity index, the UK-FTSE 4 Good Index returns, in excess of the risk-free interest rate. 


\section{DATA}

The pension fund data is obtained from Thomson Reuters. The database consists of the monthly returns obtained for all private pension funds, both conventional (2410) and SR (145), registered for sale in the United Kingdom with a domestic equity investment location, from January 1994 to September 2010.

Pension funds are required to include data for at least 24 months to ensure the consistency of the analyses. All pension funds that existed for a period of at least 24 months within the time frame considered have been taken into account, regardless of whether or not they survived until September 2010. Therefore, the sample is free of survivorship bias that could lead to inaccurate results in financial performance analyses, according to Chegut et al. (2011).

The risk-free asset and the market index are the monthly return of UK three-month Treasury Bills and the monthly total return of the FT All Share Index, respectively, obtained from Gregory et al. $(2013)^{4}$. Additionally, the UK-FTSE4Good Index is used as a market benchmark in model (10), considered as the SR risk factor.

Table 1 shows some summary statistics of the sample.

Table 1

\section{Summary statistics ${ }^{a}$}

\begin{tabular}{|c|c|c|c|c|c|}
\hline & Mean & Median & Standard deviation & Minimum & Maximum \\
\hline $\begin{array}{l}\text { Conventional pension } \\
\text { funds }\end{array}$ & 0.0048 & 0.0104 & 0.4013 & -0.9902 & 0.0456 \\
\hline SR pension funds & 0.0037 & 0.0099 & 0.1780 & -0.2010 & 0.0470 \\
\hline Market factor & 0.0063 & 0.0121 & 0.0417 & -0.1324 & 0.0994 \\
\hline Size factor (SMB) & 0.0002 & 0.0009 & 0.0243 & -0.0694 & 0.0931 \\
\hline $\begin{array}{l}\text { Book-to-market } \\
\text { factor (HML) }\end{array}$ & 0.0057 & 0.0050 & 0.0253 & -0.0957 & 0.1096 \\
\hline $\begin{array}{l}\text { Momentum factor } \\
\text { (PR1YR) }\end{array}$ & 0.0093 & 0.0131 & 0.0454 & -0.2596 & 0.1380 \\
\hline Ethical factor & 0.0003 & 0.0078 & 0.0439 & -0.1200 & 0.0917 \\
\hline
\end{tabular}

aTable 1 shows the summary statistics (mean, median, standard deviation, minimum and maximum) of the conventional pension fund return, the SR pension fund return, and the risk factor return (market, size, book-to-market, momentum and ethical).

Source: Own elaboration.

This table shows that conventional pension funds present a higher average return than the SR funds, but they also offer a higher dispersion and a considerable minimum value, while SR pension funds reach a superior maximum. Given this evidence, differences are expected in the empirical analysis.

4 Data obtained from Xfi Centre for Finance and Investment, University of Exeter: http://business-school.exeter.ac.uk/research/areas/centres/xfi/research/famafrench/disclaimer/ 


\section{EMPIRICAL RESULTS}

\subsection{Performance results}

The financial performance of conventional and SR pension funds is analyzed by implementing the CAPM and Carhart models (models 1 and 2, respectively). The CAPM results for both pension funds are presented in Table 2. Additionally, this table shows the difference between the coefficients obtained for conventional and SR funds (the significance of these differences is tested with a mean-difference t-test).

The results of the CAPM model show that both types of pension fund perform worse than the market (significantly negative risk-adjusted alphas in conventional and SR pension funds). Additionally, the performance of SR pension funds is significantly lower (0.004) than the performance of their counterparts.

Table 2

\section{Results of CAPM model ${ }^{b}$}

\begin{tabular}{lccc}
\hline & $\alpha_{0}$ & $\beta_{1}$ & $\mathrm{R}^{2}$ adj \\
\hline Conventional pension funds & $-0.0011^{* * *}$ & $0.9228^{* * *}$ & 0.7058 \\
& $(0.000)$ & $(0.000)$ & \\
SR pension funds & $-0.0015^{* * *}$ & $0.9306^{* * *}$ & 0.6149 \\
& $(0.000)$ & $(0.000)$ & \\
Difference (conventional-SR) & $0.0004^{* *}$ & -0.0078 & \\
\hline
\end{tabular}

${ }^{\mathrm{b}}$ Table 2 shows the fund average coefficients of the fund OLS estimation of the CAPM model, regression (1), for conventional and SR pension funds investing in UK domestic equity. The last row shows the coefficient differences between conventional and SR funds. The associated p-values are shown beneath the coefficients estimated in brackets. The R-squared adjusted $\left(\mathrm{R}^{2}\right.$ adj) coefficient is also included for each model estimated. *,** and *** indicate significance at the $10 \%, 5 \%$ and $1 \%$ level, respectively.

Source: Own elaboration.

The Carhart model results are displayed in Table 3. Results show that conventional and SR pension funds underperform the market (significantly negative alphas), although conventional funds obtain an inferior alpha (-0.0004 at $10 \%$ significance level). In relation to the investment styles, conventional and SR pension funds usually invest in small caps (significantly positive $\beta_{2}$ ) and growth stocks (significantly negative $\beta_{3}$ ). Similar results are found by Ferruz et al. (2012) in a US mutual fund sample, in which religious mutual funds usually invest in small caps. Moreover, both pension funds develop contrarian momentum strategies (significantly negative $\beta_{4}$ ). These results reveal that conventional and SR pension funds develop similar strategies, leading to similar (and poor) performance results. Despite this, the style coefficient differences show that SR pension funds invest in small cap companies and growth stocks to a greater extent, and their momentum strategies are even more opposite to the market. 
Table 3

Results of Carhart model ${ }^{\mathrm{c}}$

\begin{tabular}{lcccccc}
\hline & $\alpha_{0}$ & $\beta_{1}$ & $\beta_{2}$ & $\beta_{3}$ & $\beta_{4}$ & $\mathrm{R}^{2}$ adj \\
\hline $\begin{array}{l}\text { Conventio- } \\
\text { nal pension } \\
\text { funds }\end{array}$ & $-0.0009^{* * *}$ & $0.9520^{* * *}$ & $0.2396 * * *$ & $-0.0672 * * *$ & $-0.0063 * * *$ & 0.7212 \\
& $(0.000)$ & $(0.000)$ & $(0.000)$ & $(0.000)$ & $(0.000)$ & \\
$\begin{array}{l}\text { SR pension } \\
\text { funds }\end{array}$ & $-0.0005^{* *}$ & $0.9611 * * *$ & $0.4391 * * *$ & $-0.1775^{* * *}$ & $-0.0510^{* * *}$ & 0.7286 \\
& $(0.034)$ & $(0.000)$ & $(0.000)$ & $(0.000)$ & $(0.000)$ & \\
$\begin{array}{l}\text { Difference } \\
\text { (conventio- } \\
\text { nal-SR) }\end{array}$ & $-0.0004 *$ & -0.0091 & $-0.1995^{* * *}$ & $0.1103 * *$ & $0.0447 * * *$ & \\
\hline
\end{tabular}

${ }^{\mathrm{c}}$ Table 3 shows the fund average OLS estimation of the Carhart model, regression (2), for conventional and SR pension funds with domestic equity investment registered for sale in the UK and their differences. $\alpha_{0}$ represents the alpha and the performance of the model, $\beta_{1}$ represents the risk-market exposure, $\beta_{2}$ is the size factor (SMB) coefficient, $\beta_{3}$ is the book-to-market factor (HML) coefficient, and $\beta_{4}$ is the momentum factor (PR1YR) coefficient. The associated p-values are shown beneath the coefficients estimated in brackets. The R-squared adjusted coefficient is also included for each of the models estimated. *,** and *** indicate significance at the $10 \%, 5 \%$ and $1 \%$ level, respectively.

Source: Own elaboration.

\subsection{Stock-picking and market timing abilities}

In this section, the stock-picking and market timing abilities are analyzed, showing the results of the traditional and conditional TM and $\mathrm{MH}$ models (expressions 3 to 6).

The results of the traditional models are shown in Table 4. Panels A and B collect the results of conventional and SR pension funds, respectively. Panel $\mathrm{C}$ shows the difference between the conventional and SR fund results (the significance is obtained by applying a mean difference t-test).

The traditional timing models show contradictory results. The traditional Treynor-Mazuy model results show that conventional and SR pension fund managers develop incorrect stock-picking abilities (negative alpha coefficients in panels A and B). However, the Merton-Henriksson model results show positive stock-picking skill in conventional funds and absence of stock-picking in SR funds. Comparing conventional and SR funds, conventional funds present superior stock-picking skills in both models (less negative and positive skill versus negative and no skill in TM and $\mathrm{MH}$, respectively). On the other hand, both sets of pension fund managers time the market incorrectly, presenting perverse market timing abilities (significantly negative $\gamma_{1}$ in panels A and B). 
Table 4

Results of traditional timing models ${ }^{\mathrm{d}}$

\begin{tabular}{lcccc}
\hline & $\alpha_{0}$ & $\beta_{1}$ & $\gamma_{1}$ & $\mathrm{R}^{2} \mathrm{adj}$ \\
\hline Panel A: conventional pension funds & $-0.0003^{* * *}$ & $0.9114^{* * *}$ & $-0.4455^{* * *}$ & 0.7065 \\
Traditional Treynor-Mazuy model & $(0.000)$ & $(0.000)$ & $(0.000)$ & \\
& $0.0007^{* * *}$ & $0.9701^{* * *}$ & $-0.1129 * * *$ & 0.7068 \\
Traditional Merton-Henriksson model & $(0.000)$ & $(0.000)$ & $(0.000)$ & \\
& & & & \\
Panel B: SR pension funds & $-0.0009 * * *$ & $0.9209 * * *$ & $-0.3524 * * *$ & 0.6753 \\
Traditional Treynor-Mazuy model & $(0.001)$ & $(0.000)$ & $(0.000)$ & \\
& 0.0004 & $0.9806^{* * *}$ & $-0.1219^{* * * *}$ & 0.6760 \\
Traditional Merton-Henriksson model & $(0.229)$ & $(0.000)$ & $(0.000)$ & \\
& & & & \\
Panel C: Differences (conventional-SR) & & & & \\
TM & $0.0006^{* *}$ & $-0.0095^{* *}$ & $-0.0931^{* *}$ & \\
MH & $0.0003^{* *}$ & -0.0105 & 0.009 & \\
\hline
\end{tabular}

dTable 4 shows the fund average OLS estimation of the traditional Treynor-Mazuy and Merton-Henriksson models, regressions (3) and (4), for conventional pension funds (panel A) and SR pension funds (panel B) with domestic equity investment registered for sale in the UK. $\alpha_{0}$ represents the stock picking ability; $\beta_{1}$ represents the risk-market exposure; and $\gamma_{1}$ measures the market timing ability. Panel $\mathrm{C}$ shows the coefficient differences between conventional and SR pension funds. The associated p-values are shown beneath the coefficients estimated in brackets. The R-squared adjusted coefficient is also included for each of the models estimated. *,** and *** indicate significance at the $10 \%, 5 \%$ and $1 \%$ level, respectively.

Source: Own elaboration.

The results of the conditional timing models are shown in Table 5. Panels A and B show the results of the conventional and SR pension funds, respectively. Panel $\mathrm{C}$ shows the coefficient differences between both pension funds (the significance of the differences is obtained with a mean difference t-test).

The results of the conditional timing models (Table 5) support the ambiguous stock-picking results found in the traditional timing models (Table 4). Despite this, Table 5 shows that conventional funds display better stock-picking skill than SR funds (less negative selectivity ability in the conditional-TM model and positive skill in the conditional-MH model). Furthermore, the negative market timing skill previously found persists in conventional and SR pension funds. The small difference between the traditional and conditional model results reveals that managers either do not use superior information to improve their results, or they do so incorrectly. 
Table 5

Results of conditional timing models ${ }^{\mathrm{e}}$

\begin{tabular}{lcccc}
\hline & $\alpha_{0}$ & $\beta_{1}$ & $\gamma_{1}$ & $\mathrm{R}^{2}$ adj \\
\hline Panel A: conventional pension funds & & & & \\
Conditional Treynor-Mazuy model & $-0.0007^{* * *}$ & $0.9368^{* * *}$ & $-0.5368^{* * *}$ & 0.7105 \\
& $(0.000)$ & $(0.000)$ & $(0.000)$ & \\
Conditional Merton-Henriksson model & $0.0003^{* * *}$ & $0.9889^{* * *}$ & $-0.1089^{* * *}$ & 0.7105 \\
& $(0.000)$ & $(0.000)$ & $(0.000)$ & \\
Panel B: SR pension funds & & & & \\
Conditional Treynor-Mazuy model & $-0.0012^{* * *}$ & $0.9137^{* * *}$ & $-0.5125^{* * *}$ & 0.6780 \\
& $(0.000)$ & $(0.000)$ & $(0.000)$ & \\
Conditional Merton-Henriksson model & 0.0002 & $0.9719^{* * *}$ & $-0.1284^{* * *}$ & 0.6783 \\
& $(0.571)$ & $(0.000)$ & $(0.000)$ & \\
Panel C: Differences (conventional-SR) & & & & \\
Conditional TM & $0.0005^{* * *}$ & 0.0231 & -0.0243 & \\
Conditional MH & $0.0001^{* * *}$ & 0.017 & 0.0195 & \\
\hline
\end{tabular}

'Table 5 shows the fund average OLS estimation of the conditional Treynor-Mazuy and Merton-Henriksson models, regressions (5) and (6), for conventional pension funds (panel A) and SR pension funds (panel B) with domestic equity investment registered for sale in the UK. $\alpha_{0}$ represents the stock picking ability, $\beta_{1}$ represents the risk-market exposure; and $\gamma_{1}$ measures the market timing ability. Panel C shows the coefficient differences between conventional and SR pension funds. The associated p-values are shown beneath the coefficients estimated in brackets. The R-squared adjusted coefficient is also included for each of the models estimated. *,** and *** indicate significance at the $10 \%, 5 \%$ and $1 \%$ level, respectively. Source: Own elaboration.

\subsection{Style timing abilities}

In this section, the timing abilities with regard to the different management styles defined in the Fama and French (1993) and Carhart (1997) models are analyzed. Specifically, the multifactorial timing models (8) and (9) are implemented.

Table 6 exhibits these multifactoral timing model results. Panel A presents the results of the TM and MH extended versions for conventional pension funds. Panel B shows the same model results for SR funds. Panel C shows the differences between both funds (tested with a mean difference t-test).

The stock-picking results are homogenous between models and funds, revealing a negative skill. The market exposure $\left(\beta_{1}\right)$ is similar in both conventional and SR pension funds. With regard to the style strategies, conventional and SR funds invest in small cap and growth values, in line with Ferruz et al. (2010). Nonetheless, the momentum strategies are diverse: absent or positive momentum strategies in conventional funds (panel A), and contrarian momentum strategies in SR funds (panel B). Concerning market timing abilities, the results again show negative market-timing skill in conventional funds. However, the timing coefficient is positive in the TM-Carhart model and non-significant in the MH-Carhart for SR funds, which reveals some degree of superior market timing ability in SR managers. Additionally, all managers are able to time size strategies correctly (significantly positive $\gamma_{2}$ ). The timing of the book-to-market factor is not clear (negative or positive skill in conventional funds, and positive or no skill in SR funds). The timing of the momentum factor is also inconclusive, although there is a generalized negative timing, especially in SR funds. 
The abilities of managers in UK pension funds. Are socially responsible managers superior?

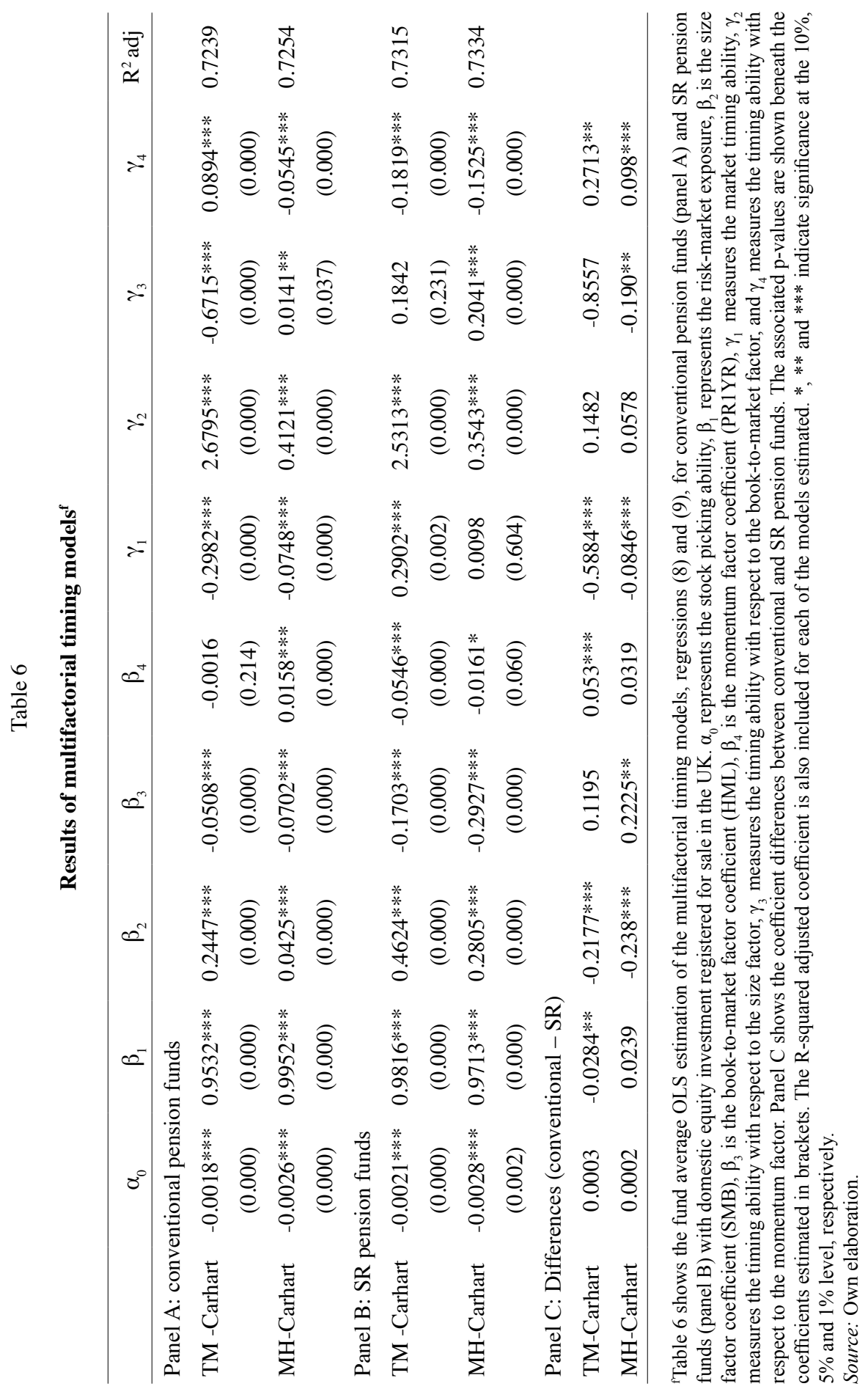


As a result, conventional and SR pension fund managers develop similar investment strategies and present negative stock-picking skills, although their timing skills differ. SR pension funds are able to time correctly more strategies (market, size and book-to-market); thus, SR funds are able to adapt to the market and their investment strategies (investing in small versus large cap companies and in growth versus value stocks) at the correct moment. Investment in past poor performers (contrarian momentum strategies) leads SR funds to develop negative momentum timing.

\subsection{The SR factor in the Carhart model}

Table 7 shows the results of model (10) to measure the impact of the SR style on fund returns.

Table 7

\section{Results of the model with SR risk factor ${ }^{\mathrm{g}}$}

\begin{tabular}{lccccccc}
\hline & $\alpha_{0}$ & $\beta_{1}$ & $\beta_{2}$ & $\beta_{3}$ & $\beta_{4}$ & $\beta_{5}$ & $\mathrm{R}^{2} \mathrm{adj}$ \\
\hline Conventional & $-0.0023^{* * *}$ & $0.8721^{* * *}$ & $0.3846^{* * *}$ & $-0.0601^{* * *}$ & $-0.0400^{* * *}$ & $0.0503^{* * *}$ & 0.7743 \\
pension funds & $(0.000)$ & $(0.000)$ & $(0.000)$ & $(0.000)$ & $(0.000)$ & $(0.000)$ & \\
$\begin{array}{l}\text { SR pension } \\
\text { funds }\end{array}$ & $-0.0016^{* * *}$ & $0.6807^{* * *}$ & $0.5263^{* * *}$ & $-0.0455^{* * *}$ & $-0.1056^{* * *}$ & $0.2456^{* * *}$ & 0.7922 \\
& $(0.000)$ & $(0.000)$ & $(0.000)$ & $(0.000)$ & $(0.000)$ & $(0.000)$ & \\
$\begin{array}{l}\text { Difference } \\
\text { (conv-SR) }\end{array}$ & $-0.0007^{* * *}$ & $0.1914^{* * * *}$ & $-0.1417^{* * *}$ & -0.0146 & $0.0656^{* * *}$ & $-0.1953^{* * *}$ & \\
\hline
\end{tabular}

${ }^{g}$ Table 7 shows the fund average OLS estimation of model (10) for conventional pension funds and SR pension funds with domestic equity investment registered for sale in the UK, and their differences. $\alpha_{0}$ represents the alpha (performance of the model), $\beta_{1}$ represents the risk-market exposure, $\beta_{2}$ is the size factor $(S M B)$ coefficient, $\beta_{3}$ is the book-to-market factor (HML) coefficient, $\beta_{4}$ is the momentum factor (PRIYR) coefficient, and $\beta_{5}$ is the SR risk factor coefficient. The associated p-values are shown beneath the coefficients estimated in brackets. The R-squared adjusted coefficient is also included for each of the models estimated. *, ** and *** indicate significance at the $10 \%, 5 \%$ and $1 \%$ level, respectively.

Source: Own elaboration.

As expected, SR pension funds have significantly positive loadings on the SR factor $\left(\beta_{5}\right)$. To observe the impact of this result on fund performance, the alpha coefficients are analyzed. The alpha is significantly negative in both funds and lower in conventional pension funds. Moreover, the alpha coefficient of the SR funds (Table 7) is significantly lower than the four-factor alpha (Table 3); specifically, -0.0011, implying that the SR risk factor influences the risk-adjusted returns, and the underperformance of SR pension funds appears to be driven by the SR risk, as Renneboog et al. (2008) find. Consequently, the SRI screening may constrain the risk-return optimization, although not excessively, since conventional funds are also unable to achieve positive performance. 


\subsection{Bootstrap comparative analysis}

In this section, a robustness test is implemented to verify that the previous results are not driven by the different sample sizes (145 SR funds versus 2,410 conventional funds). Following Fernández and Matallín (2008), a bootstrap method is applied, by forming 10,000 random subsamples of size 145 from the total group of funds, excluding the SR pension funds. Then the average and the difference between this average and that of the SR pension funds are calculated. Table 8 displays the results.

Table 8

\section{Bootstrapping results of the differences in performance and stock-picking abilities between conventional and $S R$ pension funds ${ }^{h}$}

Differences in the alphas between the subsamples of conventional pension funds and SR funds in the following models:

\begin{tabular}{lcc}
\hline CAPM & $0.0004^{*}$ & 0.057 \\
CARHART & $-0.0005^{* * *}$ & 0.007 \\
TM & $0.0006^{* * *}$ & 0.000 \\
MH & $0.0003^{* *}$ & 0.017 \\
\hline
\end{tabular}

${ }^{\text {h}}$ Table 8 represents the bootstrap results of the differences in performance and stock-picking abilities between conventional and SR pension funds. The performance is measured with the alphas of the CAPM and Carhart models and the stock-picking abilities are measured with the alphas of the Treynor-Mazuy (TM) and Merton-Henriksson $(\mathrm{MH})$ models. $*, * *$ and $* * *$ indicate significance at the $10 \%, 5 \%$ and $1 \%$ level, respectively.

Source: Own elaboration.

Table 8 collects the difference in performance and stock-picking abilities between conventional funds (bootstrap coefficients) and SR pension funds. It should be noted (not reported) that both conventional and SR alpha coefficients are negative in the CAPM and Carhart models. However, the CAPM alpha is higher in conventional pension funds, and the Carhart performance alpha is higher in SR pension funds, leading to the positive and negative differences observed, respectively, in Table 8. On the other hand, the stock picking coefficients are significantly negative in both conventional and SR pension funds, although the stock-picking ability is less negative in conventional funds, which leads to positive differences (Table 8). Consequently, the generalized underperformance and negative selectivity skills are line with the results attained in the prior sections, which indicates that the results are not driven by the size difference between the samples analyzed.

\section{CONCLUSIONS}

SRI has grown over recent decades, and financial instruments, such as SR mutual and SR pension funds have appeared. While most studies focus on mutual funds, the analysis of SR pension funds is an important topic of study because these products are both financial instruments and long-term savings vehicles, determining the future incomes of many 
savers during retirement. Consequently, this paper examines whether socially responsible pension funds implement different strategies and achieve different levels of performance than conventional funds, contributing to developing more socially responsible pension outcomes. Specifically, the performance, the styles, and the abilities of UK domestic equity pension fund managers (conventional and SR) are examined.

To date, only Ferruz et al. (2010) provide a comparative analysis of stock-picking and market timing abilities in pension funds. Accordingly, this analysis extends the existing literature on SR pension funds, with the results showing significantly negative performance and similar investment strategies in both conventional and SR pension funds. Specifically, the pension funds analyzed invest in small caps and growth stocks, and develop contrarian momentum strategies. Moreover, both types of fund present poor and negative stock-picking abilities and perverse market timing skills. Nonetheless, SR pension funds are able to correctly time more strategies (market, size, and book-to-market).

This study also controls for potential differences in style due to the SR component by introducing the SR risk factor in the model applied. The analysis shows that SR pension funds have significantly positive loadings of the SR factor, which erodes performance. As a result, the risk-return optimization of SR funds may be constrained by the fulfillment of specific SRI requirements.

Finally, a robustness test is carried out to confirm that the prior results are not driven by the size difference between both samples. A bootstrap analysis (forming subsamples of conventional funds) is applied and the results are compared between conventional and SR pension funds. The results are in line with prior outcomes, thus confirming the conclusions of the analysis.

It worth noting that significant differences between conventional and SR funds in performance, style, and timing abilities are not found. Therefore, SR investors who base their investment decisions on social and personal values, achieve similar financial results and obtain more socially responsible pensions for retirement than conventional pension fund investors.

\section{REFERENCES}

Albareda, L. and Balaguer, M.R., 2009. The Challenges of Socially Responsible Investment among Institutional Investors: Exploring the Links between Corporate Pension Funds and Corporate Governance. Business and Society Review, 114(1), 31-57.

Amalric, F., 2006. Pension funds, corporate responsibility and sustainability. Ecological Economics, 59(4), 440-450.

Bauer, R., Dewall, J. and Otten, R., 2007. The ethical mutual fund performance: New evidence from Canada. Journal of Business Ethics, 70(2), 111-124.

Bauer, R., Koedijk, K., and Otten, R., 2005. International evidence on ethical mutual fund performance and investment style. Journal of Banking and Finance, 29(7), 1751-1767.

Bauer, R., Otten, R. and Tourani, A. R., 2006. Ethical investing in Australia: Is there a financial penalty? Pacific-Basin Finance Journal, 14(1), 33-48.

Becchetti, I. and Fucito, L., 2000. La finanza etica: consideración teoriche e simulación empírica. Revista di Política Economica, 1(Maggio), 29-67. 
Bengtsson, E., 2008a. Socially responsible investing in scandinavia - a comparative analysis. Sustainable Development, 16(3), 155-168.

Bengtsson, E., 2008b. A history of scandinavian socially responsible investing. Journal of Business Ethics, 82(4), 969-983.

Berry, C., 2011. Protecting our best interests. Rediscovering fiduciary obligation. London: Fair Pensions. Available from http://www.fairpensions.org.uk/sites/default/files/ uploaded_files/fidduty/FPProtectingOurBestInterests.pdf

Bollen, N. and Busse, S., 2001. On the timing ability of mutual fund managers. Journal of Finance, 56(3), 1075-1094.

Camino, D. and López, J., 1995. Un análisis de la inversión ética en España. Boletín de Estudios Económicos, 50(156), diciembre, 519-540.

Carhart, M., 1997. On Persistence in Mutual Fund Performance. The Journal of Finance, 52(1), 57-82.

Chegut, A., Schenk, H. and Scholtens, B., 2011. Assessing SRI fund performance research: Best practices in empirical analysis. Sustainable Development, 19(2), 77-94.

Christopherson, J.A., Ferson, W.E. and Glassman, D.A., 1998. Conditioning manager alpha on economic information: another look at the persistence of performance. Review of Financial Studies, 11(1), 111-142.

Clark, G. L. and Hebb, T., 2005. Why should they care? The role of institutional investors in the market for corporate social responsibility. Environment and Planning A, 37(11), 2015- 2031.

Climent, F. and Soriano, P., 2011. Green and good? The investment performance of US environmental mutual funds. Journal of Business Ethics, 103(2), 275-287.

Cortez, M.C. and Silva, F., 2002. Conditioning Information on Portfolio Performance Evaluation: A re-examination of performance persistence in the Portuguese mutual fund market. Finance India, 16(4), 1393-1408.

Davis, B., 1999. Profits from Principle, Five Forces Redefining Business. The Futurist, 33(3), 28-33.

Derwall, J., Koedijk, K. and Ter Horst, J., 2011. A tale of values driven and profit seeking social investors. Journal of Banking and Finance, 35(8), 2137-2147.

Domini, A., Kinder, P. and Lydenberg, S., 1992. The Social Investment Almanac: A Comprehensive Guide to Socially Responsible Investing. New York: Henry Holt \& Co.

Emel, J., 2002. An Inquiry into the Greeen Financial Disciplining of Capital. Environment and Planning A, 34(5), 827-843.

Entine, J., 2005. The Politization of Public Investment. In: Entine J., ed. Pension Fund Politics. The Dangers of Socially Responsible Investing. Washington D. C.: The AEI Press, 1-12.

Eurosif, 2011. Corporate Pension Funds and Sustainable Investment Study.

Eurosif, 2016. European SRI Study 2016. European Sustainable Investment Forum.

Fama, E., and French, K., 1993. Common risk factors in the returns on stocks and bonds. Journal of Financial Economics, 33(1), 3-56.

Fernández, A. and Matallín, J.C., 2008. Performance of ethical mutual funds in Spain: sacrifice or premium? Journal of Business Ethics, 81(2), 247-260. 
Ferruz, L., Muñoz, F. and Vargas, M., 2010. Stock picking, market timing and style differences between socially responsible and conventional pension funds: evidence from the United Kingdom. Business Ethics: A European Review, 19(4), 408-422.

Ferruz, L., Muñoz, F. and Vargas, M., 2012. Managerial Abilities: Evidence from Religious Mutual Fund Managers. Journal of Business Ethics, 105(4), 503-517.

Ferson, W. and Quian, M., 2004. Conditional Performance Evaluation Revisited. United States of America: Research Foundation Monograph of the CFA Institute.

Ferson, W. and Schadt, R., 1996. Measuring Fund Strategy and Performance in Changing Economic Conditions. Journal of Finance, 51(2), 425-462.

Geczy, C., Stambaugh, R., and Levin, D., 2006. Investing in socially responsible mutual funds. Working Paper, University of Pennsylvania.

Gifford, E. J. M., 2010. Effective shareholder engagement: The factors that contribute to shareholder salience. Journal of Business Ethics, 92(Supplement 1), 79-97.

Goldreyer, E., and Diltz, D., 1999. The performance of socially responsible mutual funds: Incorporating sociopolitical information in portfolio selection. Managerial Finance, 25(1), 23-36.

Gregory, A. and Whittaker, J., 2007. Performance and performance persistence of ethical unit trusts in the UK. Journal of Business Finance and Accounting, 34(7-8), 13271344.

Gregory, A., Tharayan, R. and Christidis, A., 2013. Constructing and Testing Alternative Versions of the Fama-French and Carhart Models in the UK. Journal of Business Finance \& Accounting, 40(1-2), 172-214.

Hawley, J. P. and Williams, A. T., 2000. The rise of fiduciary capitalism. How institutional investors can make corporate America more democratic. Philadelphia: University of Pennsylvania Press.

Hawley, J. P. and Williams, A. T., 2007. Universal owners: challenges and opportunities. Corporate Governance: An International Review, 15(3), 415-420.

Hertrich, C., 2011. Strategic Asset Allocation Considerations for German Pension Insurance Funds: Theoretical Analysis and Empirical Evidence. Applying Stochastic Time Series Simulations and Dynamic, Multiperiod Investment Strategies to Determine Optimal Portfolio Structures, (C) Berlín: Christian Hertrich Druck un Verlag: epubli GmbH.

Hoepner, A., Rezee, M. and Siegl, S., 2011. Does pension funds' fiduciary duty prohibit the integration of any ESG criteria in investment processes? A realistic prudent investment test. Working paper, University of St Andrews.

Kempf, A. and Osthoff, P., 2007. The effect of socially responsible investing on portfolio performance. European Financial Management, 13(5), 908-922.

Kiernan, M. J., 2007. Universal Owners and ESG: leaving money on the table? Corporate Governance: An International Review, 15(3), 478-485.

Kreandert, N., Gray, R. H., Power, D. M., and Sinclair, C. D., 2005. Evaluating the performance of ethical and non-ethical funds: A matched pair analysis. Journal of Business Finance and Accounting, 32(7-8), 1465-1493.

Lamb, D., 1991. Morals and Money. Money Management, September, 39-46.

Lu, J., 2005. What is the Wind Behind this Sail? Can Fund Managers Successfully Time Their Investment Styles? Unpublished Doctoral dissertation, Cranfield School of Management, The Centre for Financial Research, Cranfield University, UK. 
Luther, R., Matatko, J., and Corner, D., 1992. The investment performance of UK ethical investment trusts. Accounting, Auditing and Accountability Journal, 5(4), 57-70.

Lydenberg, S. D., 2007. Universal Investors and Socially Responsible Investors: a tale of emerging affinities. Corporate Governance: An International Review, 15(3), 467-477.

Mallin, C., Saadouni, B . and Briston, R., 1995. The financial performance of ethical investment funds. Journal of Business Finance and Accounting, 22(4), 483-496.

Mattison, R., M. Trevitt, L. van Ast, J. Gifford, N. Mnatsakanian, O. Watson, C. Zimmerman, V. Piani, A. G. F. Hoepner, P. Clemens-Hunt, B. Bacani and Mulder I., 2011. Univeral Ownership: Why environmental externalities matter to institutional investors. PRI Association and UNEP Finance Initiative. New York: United Nations Environmental Programme.

Merton, R.C. and Henriksson, R.D., 1981. On market timing and investment performance II: statistical procedures for evaluating forecasting skills. The Journal of Business, 54(4), 513-534.

Munnell, A., 1983. The Pitfalls of Social Investing. New England Economic Review, September/October, 20-41.

Munnel, A. H. and Sundén A., 2005. Social Investing: Pension Plans Should Just Say "No". En: Entine, J., ed. Pension Fund Politics. The Dangers of Socially Responsible Investing: 13-55. Washington: The AEI Press.

Read, T., 1999. Ethics for Pleasure and Profit. Euromoney, 367, 12-14.

Renneboog, L., Ter Horst, J., and Zhang, C., 2008. The price of ethics and stakeholder governance: The performance of socially responsible mutual funds. Journal of Corporate Finance, 14(3), 302-322.

Richardson, B. J., 2007. Do the Fiduciary Duties of Pension Funds Hinder Socially Responsible Investment? Banking and Finance Law Review, 22(2), 145-201.

Richardson, B. J., 2008. Socially Responsible Investment Law: Regulating the Unseen Polluters. Oxford: Oxford University Press.

Richardson, B. J. and Cragg, W., 2010. Being virtous and prosperous: Sri's conflicting goals. Journal of Business Ethics, 92(Supplement 1), 21-39

Rounds, C. E. Jr., 2005. Why Social Investing Threatens Public Pension Funds, Charitable Trusts, and the Social Security Trust Fund. In: Entine, J., ed. Pension Fund Politics. The Dangers of Socially Responsible Investing. Washington: The AEI Press, 56- 80.

Roy, B. and Deb, S. S., 2004. Conditional alpha and performance persistence for Indian mutual funds: empirical evidence. ICFAI Journal of Applied Finance, 10(1), 30-48.

Sethi, S. P., 2005. Investing in Socially Responsible Companies is a Must for Public Pension Funds - Because There is no Better Alternative. Journal of Business Ethics, 56(2), 99-129.

Social Investment Forum, 2001. Report on responsible investing trends in the US. Available at: http:// www.socialinvest.org.

Solomon, J. F., 2009. Pension Fund Trustees and Climate Change. London: ACCA Research Report No. 106.

Sparkes, R. and Cowton, C. J., 2004. The maturing of socially responsible investment: A review of the developing link with the corporate social responsibility. Journal of Business Ethics, 52(1), 45-57. 
Statman, M., 2000. Socially responsible mutual funds. Financial Analysts Journal, 56(May/June), 30-39.

Thamotheram, R. and Wildsmith, H., 2007. Increasing Long-Term Market Returns: realising the potential of collective pension fund action. Corporate Governance: An International Review, 15(3), 438-454.

Treynor, J. and Mazuy, K., 1966. Can mutual funds outguess the market? Harvard Business Review, 44(4), 131-136.

UNEP Finance Initiative, 2005. A legal framework for the integration of environmental, social and governance issues into institutional investment. London: Freshfields Bruckhaus Deringer.

Waddock, S. A. and Graves S. B., 1997. The Corporate Social Performance-Financial Performance Link. Strategic Management Journal, 18(4), 303-319. 
